\title{
Pandangan Kristen tentang Kebudayaan dan Adat Istiadat di dalamnya
}

Pilemon Bukit

Sekolah Tinggi Theologia Paulus, Medan

pilemon@gmail.com

Abstract: Humans are creatures that cannot live alone and that is why humans must live in groups. Therefore social scientists call humans social beings. Humans also have thoughts, feelings and desires and human thoughts, feelings and wills are used to be able to live in the social, cultural and natural environment. Human thoughts, feelings and will result in the emergence of adaptation strategies for humans, so they can survive in their social, cultural and natural environment. Social sciences experts adopt the adaptation strategy with culture. Therefore, humans are united with their culture or in other words humans cannot live without their culture, including the customs in it. Thus, Christianity must see, understand and treat humans together with the culture and customs that are in it, so that there are no collisions that should not occur.

Keywords: Christian; culture; custom; tradition

Abstrak: Manusia itu adalah mahluk yang tidak dapat hidup sendiri dan itu sebabnya manusia itu harus hidup berkelompok. Karena itu para ahli ilmu sosial menyebut manusia sebagai mahluk sosial. Manusia juga memiliki fikiran, perasaan dan kehendak serta fikiran, perasaan dan kehendak manusia itu dipakai agar dapat hidup di lingkungan sosial, budaya dan alamnya. Fikiran, perasaan dan kehendak manusia itu mengakibatkan munculnya strategi adaptasi bagi manusia, sehingga dapat bertahan hidup di lingkungan sosial, budaya dan alamnya. Para ahli ilmu sosial menyebu strategi adaptasi itu dengan kebudayaan. Karena itu, manusia bersatu dengan kebudayaannya atau dengan kata lain manusia tidak dapat hidup tanpa kebudayaannya, termasuk adat istiadat yang ada di dalamnya. Dengan demikian, kekristenan harus melihat, memahami dan memperlakukan manusia bersamasama dengan kebudayaan dan adat istiadat yang ada di dalamnya, supaya tidak terjadi benturan-benturan yang seharusnya tidak terjadi.

Kata kunci: adat istiadat; kebudayaan; Kristen

\section{PENDAHULUAN}

Bila diperhatikan, ternyata banyak orang Kristen, menganggap kebudayaan itu adalah suatu hal yang harus ditinggalkan atau dibuang. ${ }^{1}$ Pendapat itu muncul oleh karena mereka menganggap kebudayaan itu datang atau berasal dari setan. Di sisi lain ada banyak juga

\footnotetext{
${ }^{1}$ John Chambers , Haskarlianus Pasang, Cara Pandang Kristen (Langham, Bogor, 2015), 169.
} 
orang Kristen menganggap kebudayaan itu adalah hal yang harus diikuti dan dipelihara. Mereka menganggap, bahwa kebudayaan itu juga datang dari Tuhan, sehingga kebudayaan dapat disejajarkan dengan Firman Tuhan, ${ }^{2}$ bahkan ada orang lebih patuh kepada ajaran kebudayaan (adat istiadat) dari pada kepada ajaran Alkitab. Arie de Kuiper mengatakan bila Injil disesuaikan dengan kebudayaan, maka bahaya sinkritisme selalu mengancam di sini, terlebih-lebih apabila keaslian Injil dikorbankan demi keaslian kebudayaan. ${ }^{3}$ Di sisi lain lagi, ada orang yang menganggap kebudayaan itu adalah berkat Tuhan, yang seharusnya dipakai untuk memberkati manusia dalam masyarakatnya, di mana kebudayaan tersebut dipraktekkan. Artinya bila kebudayaan itu sejalan, tidak bertentangan dan menolong orang Kristen untuk bertumbuh dalam iman dan pengetahuan akan Firman Tuhan, maka kebudayaan itu harus diterima dengan baik. ${ }^{4}$ Kebudayaan itu adalah berasal dari manusia dengan tujuan mensejahterakan manusia selama hidupnya di dunia ini, sementara Alkitab atau Firman Tuhan itu datang dari Tuhan dengan tujuan mensejahterakan manusia selama hidupnya di dunia ini dan sampai selamanya.

Mengapa orang Kristen memiliki sikap yang seperti itu terhadap kebudayaan tersebut? Sikap yang seperti yang barusan disebutkan di atas terjadi, sangat tergantung dari pengenalannya masing-masing terhadap kebudayaan dan juga terhadap Alkitab sebagai sumber ajaran Kristen. Orang Kristen harus memiliki cara pandang Kristen terhadap segala sesuatu. Memiliki cara pandang Kristen berati menjalani kehidupan di dunia dari sudut pandang kekekalan dan maksud semula dari penciptaan. ${ }^{5}$ Dengan orang Kristen memiliki cara pandang Kristen yang tepat, maka hal itu akan menolong orang Kristen itu untuk mengerti tujuan Allah yang sebenarnya dalam menciptakan langit, bumi dengan segala isinya. ${ }^{6}$ Dan bila orang Kristen menggunakan fikiran Kristen untuk mengembangkan cara pandang Kristen yang ada pada dirinya, maka itu akan membantu orang Kristen tersebut untuk bertumbuh secara rohani, sehingga menjadi semakin dewasa dan semakin serupa dengan Kristus, seperti yang diharapkan. ${ }^{7}$

\section{Pengertian Kebudayaan}

Defenisi kebudayaan secara etimologi (asal kata): berasal dari bahasa Sansekerta "buddhayah". Kata ini adalah kata jamak dari "buddhi" yang berarti "budi" atau akal dan "dayah" berarti kemampuan. Dengan demikian kata kebudayaan dapat diartikan menjadi "hal-hal yang bersangkutan dengan hasil berakal". ${ }^{8}$ Ada ahli juga mengatakan kata budaya itu berasal dari kata budi - daya, yang berarti daya dari budi atau kemampuan dari akal.

\footnotetext{
${ }^{2}$ Ibid., 166

${ }^{3}$ Arie de Kuiper, Missiologia (Jakarta: BPK Gunung Mulia, 2010), 91

${ }^{4}$ Chambers, Pasang, Cara Pandang Kristen, 166

${ }^{5}$ Ibid., 40.

${ }^{6}$ Ibid., 45 .

${ }^{7}$ Ibid., 61 .

${ }^{8}$ Koentjaraningrat, Pengantar Ilmu Antropologi_Jakarta : Rineka Cipta, 2009), 181. Lihat juga: Aan Rukmana dan Eddie Lembong, "Penyerbukan Silang Antarbudaya Membangun Manusia Indonesia, Editor Sahrul Mauludi, (Jakarta: Kompas Gramedia, 2015), xiii.
} 
Dengan pengertian ini, mereka membedakan antara budaya dan kebudayaan. Budaya itu adalah daya dari budi, yaitu berupa cipta, karsa dan rasa sementara itu kebudayaan itu, mereka katakan adalah hasil dari cipta, karsa dan rasa itu sendiri.

Defenisi kebudayaan menurut ahli Antropologi, khususnya Koentjaraningrat yang dapat dikatakan sebagai ahli Antropologi terkemuka di Indonesia: "kebudayaan adalah keseluruhan sistem gagasan, tindakan dan hasil karya manusia dalam rangka kehidupan masyarakat, yang dijadikan milik dari manusia dengan belajar." ${ }^{\text {9 }}$ Dengan demikian dapat dikatakan, menurut para ahli Antropologi kebudayaan itu ternyata sangat luas, dalam dan tinggi, karena mencakup semua yang ada di dalam fikiran, tindakan dan hasil karya manusia dalam rangka kehidupannya di dalam kehidupan sosial, budaya dan alamnya. Dengan demikian bisa juga dikatakan, bahwa kebudayaan itu adalah strategi hidup manusia di dalam masyarakatnya, sehingga dia dapat bertahan untuk hidup dilingkungan sosial, budaya dan alamnya serta strategi itu harus dipelajari, sehingga manusia dapat menguasainya. Di mana semuanya itu, dapat dijadikan milik oleh manusia secara terus menerus atau turun temurun melalui proses belajar.

Proses belajar ini bisa bersifat formal dan bisa juga bersifat nonformal. Jadi di mata Antropolog dan Sosiolog bila mereka berbicara tentang kebudayaan, maka mereka berbicara tentang kebudayaan sebagai perilaku manusia. ${ }^{10}$ Sejalan dengan itu, John Chambers mengatakan budaya atau kebudayaan adalah suatu cara hidup yang dikembangkan dan dimiliki bersama oleh kelompok masyarakat dan diwariskan dari generasi ke generasi. ${ }^{11}$

\section{Wujud Kebudayaan}

Menurut ahli Antropologi kebudayaan itu memiliki tiga wujud ${ }^{12}$, yaitu: sistem budaya, sistem sosial dan benda-benda budaya. Wujud yang pertama adalah sebagai satu kompleks dari ide-ide, gagasan-gagasan, nilai-nilai, norma-norma, peraturan-peraturan, adat istiadat dan lain sebagainya yang hidup dan diberlakukan di tengah-tengah masyarakat di mana kebudayaan itu berada. Wujud kebudayaan yang pertama ini bersifat abstrak, sehingga tidak dapat difoto atau diraba, karena tempatnya ada dalam fikiran warga masyarakat di mana kebudayaan itu hidup. Wujud yang pertama ini biasa juga disebut oleh ahli Antropologi sebagai sistem budaya. ${ }^{13}$ Contoh kebudayaan wujud yang pertama ini adalah: ide-ide; gagasan-gagasan, nilai-nilai, norma-norma, peraturan-peraturan, adat istiadat dan hal-hal yang berkaitan dengan fikiran manusia itu dan tempatnya ada di fikiran atau otak manusia sebagai pribadi dan juga sebagai komunitas manusia (masyarakat) di mana kebudayaan itu hidup dan dipraktekkan oleh manusia di dalam kelompoknya.

\footnotetext{
${ }^{9}$ Koentjaraningrat, Pengantar Ilmu Antropologi, 180

${ }^{10}$ Aan Rukmana dan Eddie Lembong Penyerbukan Silang Antarbudaya Membangun Manusia Indonesia, xiii

${ }^{11}$ Chambers, Pasang, Cara Pandang Kristen , 165.

${ }^{12}$ Koentjaraningrat, Pengantar Ilmu Antropologi, 186

${ }^{13}$ Ibid., 187
} 
Wujud yang ke dua: wujud kebudayaan sebagai kompleks aktivitas dan tindakan berpola dari manusia dalam masyarakatnya. Kompleks aktivitas dan tindakan berpola dari manusia di dalam masyarakatnya itu berdasar dari wujud budaya yang pertama yang sudah disebutkan di atas. Wujud yang ke dua ini biasa disebut oleh ahli Antropologi dengan sebutan sistem sosial, karena membahas tentang tindakan berpola dari manusia itu sendiri. Wujud yang ke dua atau biasa juga disebut dengan sistem sosial ini terdiri dari aktivitasaktivitas manusia yang berinteraksi dan bergaul di dalam kehidupannya di tengah-tengah masyarakat. Dimana interaksi itu selalu sesuai dengan pola-pola tertentu yang berdasarkan ide-ide, gagasan-gagasan, nilai-nilai, norma-norma, peraturan-peraturan, adat istiadat yang ada dalam masyarakat itu. Wujud yang ke dua ini, bersifat nyata dan konkrit, sehingga dapat diamati, didokumentasikan. ${ }^{14}$ Dengan kata lain, sistem sosial atau bisa juga disebut dengan pola tingkah laku seseorang dalam masyarakatnya ini, sangat dipengaruhi oleh sistem budaya yang hidup dalam masyarakat, di mana orang itu menjalankan aktivitas hidupnya. Sistem budaya itu adalah aturan kehidupan di dalam masyarakatnya dan sistem sosial itu adalah prilakuk hidup yang sesuai dengan aturan kehidupan yang ada di dalam masyarakatnya.

Contoh wujud kebudayaan yang ke dua itu:1) orang dari sub suku-bangsa Batak ${ }^{15}$ yang manapun (Karo, Simalungun, Pak-pak, Toba, Mandailing dan Angkola) diharuskan bertingkahlaku sopan kepada saudara laki-laki dari ibunya, karena begitulah sistem budayanya atau adat istiadat yang mengaturnya ("somba marhula-hula"/Batak Toba; "mehamat man kalimbubu"/Batak Karo); 2) orang Batak yang manapun umumnya menganggap pernikahan yang ideal itu adalah dengan "pariban" (Batak Toba, Simalungun, Mandailing dan Angkola) atau "impal" (Batak Karo), karena begitulah sistem budaya atau adat istiadat yang mengaturnya.

Wujud yang ke tiga: wujud kebudayaan sebagai benda-benda hasil karya, rasa dan cipta manusia. Wujud yang ke tiga ini konkrit, sehingga bisa diraba, dipegang, dilihat dan difoto.. Wujud yang ke tiga ini, biasa disebut oleh ahli Antropologi sebagai benda-benda budaya, hasil karya manusia dan kebudayaan fisik. ${ }^{16}$ Contoh wujud kebudayaan yang ke tiga ini adalah seperti bangunan-bangunan, lukisan-lukisan, sisiran rambut, pangkasan rambut, bunyi-bunyian, benda-benda lain yang dibuat oleh tangan manusia atau yang dihasilkan oleh karya dan perbuatan manusia mulai dari yang sederhana maupun yang canggih, yang sangat besar maupun yang sangat kecil.

Dikaitkan dengan pengertian di atas, maka ke tiga wujud ini dibutuhkan oleh manusia dalam rangka kehidupannya di tengah-tengah kehidupan sosial, budaya dan alamnya serta semuanya itu bisa dikuasai oleh manusia harus dengan jalan belajar, apalah belajar formal maupun belajar informal dan bahkan melalui proses waktu yang panjang.

\footnotetext{
${ }^{14}$ Ibid.

${ }^{15}$ Payung Bangun, Manusia dan kebudayaan di Indonesia (Jakarta Djambatan, 2002), 94-95

${ }^{16}$ Koentjaraningrat, Pengantar Ilmu Antropologi, 188
} 


\section{Unsur-unsur Kebudayaan}

Menurut ahli Antropologi, kebudayaan itu memiliki 7 unsur yang bersifat universal atau ada pada setiap kebudyaan suku-bangsa yang ada di dunia ini, yaitu:1) bahasa, 2) sistem pengetahuan, 3) organisasi sosial, 4) sistem peralatan hidup dan teknologi, 5) sistem mata pencaharian, 6) Sistem religi dan 7) kesenian. ${ }^{17}$ Unsur-unsur kebudayaan yang sudah disebutkan di atas, dapat diuraikan dalam beberapa bentuk.

Pertama, bahasa, baik dalam bentuk lisan, tulisan, bahasa tubuh dan isyarat lainnya merupakan karya manusia dan sangat dibutuhkan dalam rangka kehidupan manusia, supaya manusia dapat bertahan hidup dilingkungan sosial, budaya dan alamnya. ${ }^{18}$ Bahasa itu dibutuhkan dan dipakai oleh mausia di dalam dia berelasi dan berkomunikasi dengan sesamanya di dalam masyarakatnya dan bahkan dengan msyarakat manusia lainnya yang ada di luar kelompoknya. Bahasa itu mencakup bahasa tulisan, bahasa lisan, bahasa isyarat, bahasa simbol, bahasa tubuh dan lain sebagainya. Bahasa itu bisa dikuasai oleh manusia melalui proses belajar.

Kedua, sistem pengetahuan adalah karya manusia dan ada pada manusia dalam rangka kehidupan manusia dalam masyarakatnya, supaya manusia bisa bertahan hidup dilingkungan sosial, budaya dan alamnya. Sistem pengetahuan ini meliputi pengetahuan mengenai alam, flora, fauna, tubuh manusia, prilaku manusia, peralatan dan teknologi serta lain-lain sebagainya yang ada di sekitar di mana manusia itu menjalani kehidupannya. ${ }^{19}$ Dengan sistem pengetahuan yang sedemikian itu, maka manusia dapat bertahan hidup di lingkungan sosial, budaya dan alamnya. Sistem pengetahuan itu bisa dikuasai oleh manusia melalui proses belajar, baik formal maupun informal.

Ketiga, organisasi sosial adalah karya manusia dan ada pada manusia dalam rangka kehidupan manusia, supaya manusia bisa bertahan hidup dilingkungan sosial, budaya dan alamnya. Organisasi sosial itu bisa dikuasai oleh manusia melalui proses belajar, baik formal maupun informal, baik dimasyarakat tradisional maupun modern. Menurut Koentjaraningrat: "Dalam tiap masyarakat, kehidupan masyarakat diorganisir atau diatur oleh adat-istiadat dan aturan-aturan mengenai berbagai macam kesatuan di dalam lingkungan mana ia hidup dan bergaul dari hari ke hari. ${ }^{20}$ Dalam masyarakat tradisional, kehidupan manusia di dalam masyarakatnya diatur oleh adat-istiadat, sehingga mencapai keteraturan, kesejahteraan atau kebahagiaan dan di dalam masyarakat modern, kehidupan manusia di dalam masyarakatnya diatur oleh peraturan-peraturan atau undang-undang, keteraturan, kesejahteraanatau kebahagiaan.

Keempat, sistem peralatan hidup dan teknologi adalah karya manusia dan ada pada manusia dalam rangka kehidupan manusia, supaya manusia bisa bertahan hidup di lingkungan sosial dan lamanya. Sistem peralatan hidup dan teknologi, mulai dari alat-lat

\footnotetext{
${ }^{17}$ Ibid., 203-204

${ }^{18}$ Ibid., 339

${ }^{19}$ Ibid., 373

${ }^{20}$ Ibid., 366
} 
produktif, senjata, wadah, makanan, pakaian, tempat berlindung dan perumahan, alat-alat transport dan lain sebagainya. Semuanya ini dimiliki oleh manusia, mulai dari manusia dari masyarakat tradisional sampai modern. ${ }^{21}$ Dan sistem peralatan hidup dan teknologi itu bisa dikuasai atau dikendalikan oleh manusia melalui proses belajar, baik formal maupun informal. Proses beajar ini berlaku, baik dimasyarakat tradisional maupun modern.

Kelima, sistem mata pencaharian hidup adalah karya manusia dan ada pada manusia dalam rangka kehidupan manusia, supaya manusia bisa bertahan hidup dilingkungan sosial, budaya dan alamnya. Manusia dalam masyarakatnya, dari segala zaman, mulai dari zaman manusia masyarakat tradisional sampai kepada masyarakat modern, memiliki sistem mata pencaharian, agar manusia itu dapat bertahan untuk hidup di tengah-tangah lingkungan sosial, budaya dan alamnya. ${ }^{22}$ Dan sistem mata pencaharian hidup itu, bisa dikuasai oleh manusia melalui proses belajar, baik formal maupun informal. Proses belajar itu, berlaku baik bagi masyarakat tradisional maupun modern.

Keenam, sistem religi adalah karya manusia dan ada pada manusia dalam rangka kehidupan manusia, supaya manusia bisa bertahan hidup dilingkungan sosial dan lamanya. Sistem religi itu bisa dikuasai oleh manusia melalui proses belajar, baik formal maupun informal, baik dimasyarakat tradisional maupun modern. Karena itu, manusia dalam masyarakatnya akan memiliki religi (agama), baik manusia dari masyarakat tradisional maupun manusia dari masyarakat modern. Dalam mempelajari dan menguasai proses beragama dengan rinci, maka manusia itu harus belajar dan tentu cara beragama tergantung agamanya masing-masing, termasuk tempat upacara keagamaan dilakukan, saat atau waktu upacara agama dilakukan, benda-benda atau alat-alat upacara agama yang dibutuhkan, orang-orang yang bisa mengikuti upacara agama, orang-orang yang bisa memimpin upacara keagamaan dan lain sebagainya. ${ }^{23}$ Secara umum, manusia dapat mengerti dan menguasai proses beragama di agamanya itu harus melalui proses belajar.

Ketujuh, kesenian adalah karya manusia dan ada pada manusia dalam rangka kehidupan manusia, supaya manusia bisa bertahan hidup dilingkungan sosial dan lamanya. Kesenian itu bisa dikuasai oleh manusia melalui proses belajar, baik formal maupun informal, baik dimasyarakat tradisional maupun modern. Kesenian itu bukan hanya sekedar asesori kehidupan, tetapi kebutuhan kehidupan manusaia dalam masyarakatnya, sehingga bisa dikatakan, manusia tidak bisa menjalani kehidupannya, tanpa kesenian. Kesenian itu beragam, seperti senirupa (patung, relief, lukis atau gambar dan rias), seni suara (vocal, instrumental dan sastra), seni tari, seni drama dan lain sebagainya. ${ }^{24}$ Bisa dilihat dalam kehidupan mausia dalam masyarakatnya selalu melibatkan kesenian di dalamseluruh upacara lingkaran hidupnya, kelahiran, menikah, memasuki rumah baru, meninggal, pesta menabur benih, pesta panen dan lain sebagainya.

\footnotetext{
${ }^{21}$ Ibid., 341-357.

${ }^{22}$ Ibid., 357-366.

${ }^{23}$ Ibid., 377-378.

${ }^{24}$ Ibid., 381
} 
Ketujuh unsur kebudayaan itu adalah karya manusia dan ada di dalam masyarakat, di mana hal itu dibutuhkan dalam rangka kehidupan manusia di dalam lingkungan sosial, budaya dan alamnya. Misalnya seperti yang sudah disebutkan di atas, bahwa bahasa atau unsur-unsur yang lainnya, sangat dibutuhkan dalam rangka kehidupan manusia dalam lingkungan sosial dan alamnya. Ketujuh unsur kebudayaan yang sudah disebutkan di atas hanya bisa menjadi milik atau dikuasai oleh manusia, melalui proses belajar. Proses belajar itu bisa bersifat formal dan bisa juga bersifat informal serta dilakukan selama manusia itu hidup di dunia ini. Misalnya bahasa atau unsur kebudayaan yang lainnya hanya bisa dikuasai dan dimanfaatkan oleh manusia dalam rangka kehidupannya di tengah-tengah lingkungan sosial dan alamnya melalui proses belajar seumur hidup, apakah formal di sekolah atau informal di rumah atau di lingkungan tempat tinggal manusia itu.

Pemimpin dan kaum intelektual perlu menggali kebudayaan suku-suku bangsa di Indonesia yang positif, misalnya suku-bangsa Jawa rajin, tahan menderita dan bersih, sukubangsa Minangkabau hemat dan pekerja keras, sub suku-bangsa Batak Toba pekerja keras dan mengerjakan pekerjaan apa saja, sub suku-bangsa Batak Karo pekerja keras dan suka bergotongroyong (raron) dan lain sebagainya. Kemudian kebudayaan yang baik itu disosialisasikan dan di hidupkan di tengah-tengah kehidupan pribadi, keluarga, masyarakat, bangsa dan Negara, sehingga kehidupan pribadi, keluarga, masyarakat, bangsa dan Negara menjadi semakin maju dan lebih mudah mencapai kehidupan yang adil, makmur dan sentausa, seperti cita-cita kemerdekaan Republik Indonesia.

\section{Perubahan Kebudayaan}

Perubahan masyarakat dan kebudayaan pasti akan terjadi. Perubahan masyarakat dan kebudayaan itu secara teori dapat dipisahkan, namun di dalam kenyataan hidup manusia tidak dapat dipisahkan sama sekali. ${ }^{25}$ Kebudayaan yang dimiliki oleh masyarakat manusia itu, pastilah memiliki perubahan-perubahan, karena masyarakatnya sendiri berubah. Taufik Abdullah mengatakan hanyalah kebudayaan yang sangat terpenci yang mungkin bisa berlagak, bahwa dirinya murni otentik. ${ }^{26}$ Perubahan kebudayaan itu dapat dilihat melalui kehidupan masyarakat, meliputi nilai-nilai dan perilaku hidup yang dilakukan manusia di dalam kehidupan masyarakatnya sehari-hari. Perubahan kebudayaan itu, bisa bersifat lambat dan bisa juga bersifat cepat di satu sisi serta disisi lain bisa bersifat sebagian kecil saja dan bisa juga bersifat menyeluruh.

Hal-hal yang mengakibatkan perubahan kebudayan adalah: 1) perubahan kebudayaan itu dapat terjadi oleh karena pengaruh perubahan lingkungan sosial. Misalnya ketika manusia bertambah banyak, maka kebudayaanya juga akan berubah, supaya manusia dapat bertahan hidup dilingkungan sosial, budaya dan alamnya itu. Dengan bertambahnya jumlah

\footnotetext{
${ }^{25}$ Jacobus Ranjabar, Perubahan Sosial Teori-teori dan Prosse Perubahan Sosial Serta Teori Pembangun (Bandung: Alfabeta, 2015), 177

${ }^{26}$ Taufik Abdullah, "Fertilisasi Silang Antarbudaya: Pengalaman Bangsa Indonesia", Penyerbukan Silang Antarbudaya Membangun Manusia Indonesia, Editor Sahrul Mauludi, (Jakarta: Kompas Gramedia, 2015), 37
} 
manusia, maka bertambah jugalah kebutuhan manusia, seperti sandang, pangan, papan dan hal-hal lainnya. Dengan bertambahnya kebutuhan manusia, maka kebudayaan manusia untuk memenuhi kebutuhannya di atas harus berubah juga; 2) perubahan kebudayaan itu dapat juga terjadi karena pengaruh lingkungan alamyang berubah. Misalnya lahan tempat manusia beraktivitas yang semakin "sempit", seperti lahan untuk mata pencaharian dan tempat tinggal, maka kebudayaannya berubah, seperti membuat cara dan aturan baru untuk menata lahan yang ada, sehingga kebutuhan hidup dapat dicukupkan dan dengan demikian manusia dapat bertahan hidup di lingkungan alamnya yang berubah itu; 3) di samping hal yang sudah disebutkan di atas, perubahan kebudayaan juga dapat diakibatkan karena fikiran, perasaan dan kehendak manusia itu sendiri.

Gabungan antara fikiran, perasaan dan kehendak manusia itu selalu menemukan penemuan-penemuan baru, terlebih-lebih karena adanya tantangan, masalah dan kesulitan hidup yang dihadapi oleh manusia. Bila manusia bertambah banyak, maka maka manusia akan memasimalkan proses berfikir, berassa dan berkehendaknya, sehingga manusia dan masyarakatnya dapat bertahan hidup dilingkungan sosial dan alamnya itu. Dengan demikian akan ada penemuan-penemuan baru yang sekaligus membawa perubahan pada manusia itu, sehingga sekaligus akan membawa perubahan juga kepada kebudayaannya. Demikian juga dengan adanya perubahan dalam teknologi, termasuk teknologi transportasi manusia, maka akan terjadi perbuhan dalam mobilitas manusia, perubahan sistem nilai dan juga perubahan pola tingkah laku dari manusia itu sendiri.

Perkembangan ilmu pengetahuan dan teknologi yang adalah merupakan hasil proses berfikir, berasa dan berkehendak manusia, tentu mendatangkan perubahan pola fikir dan pola tingkah laku, sehingga bisa beradaptasi dengan perkembangan itu dan hal itu tentu saja akan membawa perubahan kepada kebudayaan manusia dalam masyarakatnya. Contoh yang berkaitan dengan teknologi transportasi manusia, awalnya mobilitas manusia dilakukan dengan berjalan kaki. Manusia merasa kurang enak dengan berjalan kaki dan manusia menginginkan yang lebih enak, maka manusia berfikir bagaimana membuat lebih enak. Maka manusia menunggangi binatang di dalam dia bergerak. Melalui proses berasa, berkehendak dan berfikir di atas, lalu manusia kemudian mengendarai kereta binantang, kapal lau di laut, mobil di darat dan pesawat di udara dalam pergerakannya. Jadi dari situ dapat dilihat dengan jelas, bahwa fikiran, perasaan dan kehendak manusia dapat mengakibat perubahan kepada kebudayaan manusia di dalam masyarakatnya.

\section{Tujuan Kebudayaan}

Di dalam defenisi kebudayaan yang dibuat oleh para ahli Antropologi di atas sebenarnya, kita sudah dapat melihat tujuan dari kebudayaan, yaitu: agar manusia dapat bertahan hidup dilingkungan sosial dan alamnya selama hidup di dunia. Bertahan hidup yang dimaksudkan di sini adalah hidup di dalam keadilan, kemakmuran dan kesentausaan atau hidup damai (damai, aman, menyenangkan, adil dan indah). Tentunya kebudayaan yang dimaksudkan tidak melanggar aturan yang ada, minimal tidak melanggar atura yang dibuat oleh 
pemerintah di mana kebudayaan itu berlaku dan dihidupi oleh masyarakatnya. Namun kemudian kebudayaan itu, mengatur dan bahkan memaksa manusia di dalam masyarakatnya untuk tunduk kepada kebudayaan itu dan hal ini membuat manusia dalam masyarakatnya menderita, ${ }^{27}$ pada hal diharapkan dari defenisi kebudayaan menurut Antropolog di atas, tujuan kebudayaan itu adalah agar manusia dapat bertahan untuk hidup dan bukan agar manusia mengalami penderitaan di dalam proses kehidupannya.

\section{Adat Istiadat dan pengertiannya}

Adat istiadat adalah bagian dari kebudayaan ${ }^{28}$, yaitu adat istiadat itu ada di dalam wujud kebudayaan yang pertama (sistem budaya yaitu: sebagai suatu kompleks dari ide-ide, gagasan-gagasan, nilai-nilai, norma-norma, peraturan-peraturan, adat istiadat dan lain sebagainya). Secara sederhana pengertian adat istiadat adalah apa yang dianggap baik oleh manusia dalam masyarakatnya, kemudian hal itu dilakukan secara berulang-ulang dan kemudian dijadikan menjadi aturan di dalam kehidupan masyarakat tersebut, sehingga kehidupan dapat menjadi lebih baik dan teratur, sehingga lebih mudah mencapai kehidupan yang adil, makmur dan sentausa atau hidup damai (damai, aman, menyenangkan, adil dan indah). Sejajar dengan itu John Chamber mengatakan, bahwa adat istiadat itulah yang membedakan antara satu suku-bangsa dengan suku-bangsa yang lainnya. Dan adat istiadat itu tidak hanya sekedar menjadi identitas diri dari satu suku-bangsa, tetapi juga cara sukubangsa itu memandang kehidupan dan kematian.

Adat istiadat itu juga mengatur bagaimana manusia dari masyarakat suku-bangsa itu, agar terhindar dari bahaya dan agar mendapat berkat. ${ }^{29}$ Contoh adat istiadat pernikahan orang Batak (Karo, Simalungun, Pak-pak, Toba, Mandailing dan Angkola) yang dianggap ideal atau baik adalah dengan "impal" (Batak Karo) atau "pariban" (Batak Toba, Simalungun, Mandailang dan Angkola), baik untuk perempuan dengan anak laki2 dari kelompok pengambil anak dara (pariban/Toba, Simalungun, Angkola dan Mandailing, impal/Karo dan Pak-pak), dan juga untuk laki2 dengan anak perempuan dari kelompok pemberi anak dara (pariban/Toba, Simalungun, Angkola dan Mandailing, impal/Karo dan Pak-pak). Pernikahan yang dianggap ideal ini biasanya mengikuti rangkaian proses yang agak panjang, mulai dari baik perkenalan, peminangan dan pengesasahan pernikahan secara adatistiadat dan agama dan bila dilakukan tidak dilakukan sesuai dengan proses yang seharusnya, maka itu dianggap mempermalukan keluarga.

\section{Tujuan adat istiadat}

Di dalam defenisi kebudayaan yang dibuat oleh para ahli Antropologi di atas sebenarnya, sudah dapat melihat tujuan dari adat istiadat, begitu juga dengan pengertian adatistiadat di atas, yaitu: agar manusia dapat bertahan hidup dilingkungan sosial dan alamnya selama

\footnotetext{
${ }^{27}$ Arie Chandra, "Peran Kebudayaan untuk Kemajuan Bangsa", Penyerbukan Silang Antarbudaya membangun Manusia Indonesia, 2

${ }^{28}$ Chambers, Pasang, 165

${ }^{29}$ Ibid., $165-166$.
} 
manusia itu hidup di dunia ini. Bertahan hidup yang dimaksudkan di sini adalah di mana manusia hidup lebih tertata, sehingga semakin mengalami keadilan, kemakmuran dan kesentausaan hidup atau hidup damai (damai, aman, menyenangkan, adil dan indah). John Chamber mengatakan adat istiadat itu mengatur, bagaimana caranya agar terhindar dari bahaya dan agar mendapat berkat. ${ }^{30}$ Hal itu dapat dilihat, bagaimana adatistiadat itu dipraktekkan di dalam upacara lingkaran hidup manusia, mulai dari kelahiran, pernikahan, kematian dan lain sebagainya.

Misalnya pernikahan orang Batak (Karo, Simalungun, Toba, Pak-pak, Mandailing dan Angkola) yang manapun tidak boleh sembarangan, ada prosesnya dan melibatkan seluruh keluarga, yaitu keluarga bapak, keluarga besar pemberi anak dara, keluarga besar pengambil anak dara, sahabat, warga sekampung dan lain sebagainya. Dan seperti yang sudah disebutkan sebelumnya pernikahan yang dianggap ideal dalam pernikahan orang Batak adalah dengan anak dari saudara laki-laki ibu untuk anak laki-laki dan anak dari saudara perempuan ayah untuk perempuan (impal $=$ Karo; pariban $=$ Simalungun, Toba, Mandailing dan Angkola).

\section{Hubungan Manusia, Masyarakat dan Kebudayaan}

Manusia adalah mahluk sosial, sehingga manusia tidak akan dapat hidup tanpa bergaul, bersahabat dan berteman dengan manusia yang lainnya dan itu jugalah sebabnya manusia tidak dapat dipisahkan dari manusia lain. Manusia itu harus bergaul (bersosialisasi), sehingga jati dirinya sebagai manusia benar-benar dapat dihidupi. Karena itu, supaya manusia dapat bertahan hidup dalam lingkungan sosial, budaya dan alamnya, maka manusia harus memiliki kebudayaan (lihat defenisi kebudayaan yang dibuat oleh Antropolog di atas). Dalam melakukan proses ini, manusia harus mempergunakan fikiran, perasaan dan kehendaknya yang dihubungkan dengan lingkungan sosial, budaya dan alam di mana dia berada.

Manusia tidak boleh mengabaikan keberadaan lingkungan sosial, budaya dan alam di mana dia menjalankan kehidupannya, di dalam dia mengambil keputusan dan melakukan proses perjalanan kehidupannya, walau sebagai pribadi. Dengan demikian bisa dikatakan, manusia itu tidak dapat hidup tanpa kelompok manusia lain atau masyarakatnya, karena dia adalah mahluk sosial (bergaul, berteman dan bersahabat). Di dalam manusia berelasi atau bergaul antara satu dan yang lainnya, maka dengan demikian timbullah kemlompok manusia atau masyarakat dan untuk menata kehidupan manusia dalam masyarakat itu manusia membutuhkan kebudayaannya sebagai pedomannya. Karena itu, harus dikatakan, bahwa manusia tidak akan dapat bertahan hidup di dalam lingkungan sosial, budaya dan alamnya tanpa kebudayaannya, termasuk adat istiadatnya. ${ }^{31}$

\footnotetext{
${ }^{30}$ Ibid., 166.

${ }^{31}$ Koentjaraningrat, Pengantar Ilmu Antropologi, 220-221
} 


\section{Kekristenan dan Keselamatan}

Sebutan Kristen bisa ditujukan kepada pengikut Yesus Kristus atau orang yang sudah percaya kepada Yesus Kristus atau orang yang sudah percaya dan menerima Yesus kristus sebagai Tuhan dan Juruselamatnya (Yoh. 1: 12; 3: 16). Istilah Kristen pertama sekali muncul di jemaat Anthiokia dan istilah itu ditujukan kepada kepada murid-murid atau orang yang sudah percaya dan beriman kepada Yesus (Kis. 11: 26). Oleh rasul Yohanes mereka yang percaya dan menerima Yesus itu diberi kuasa menjadi anak-anak Allah (Yoh. 1: 12) dan oleh Paulus mereka yang sudah menjadi anak-anak Allah itu, maka mereka menjadi ahli waris Allah (Rm. 8: 17).

Menurut Harun Hadiwijono, bahwa "beriman itu berarti mengamini dengan segenap kepribadian dan cara hidupnya kepada janji Allah, bahwa Ia di dalam Kristus telah mendamaikan orang berdosa dengan diriNya sendiri, sehingga segenap hidup orang yang beri dikuasai oleh keyakinan yang demikian itu."32 Sementara Bruce Milne mengatakan sebutan Kristen ditujukan kepada orang-orang yang sudah bersatu dengan Kritus melalui iman kepada Kristus. ${ }^{33}$ Di pihak lain, sebutan Kristen juga ditujukan kepada salah satu nama agama yang diakui, secara khusus di Indonesia. ${ }^{34}$

Alkitab sendiri telah menceritakan dengan terus terang dan sangat tegas, bahwa Yesus Kristus adalah juru selamat yang disiapkan oleh Allah bagi manusia (Yoh. 3: 16, 14: 6 dll). Di dalam Alkitab dikatakan, bahwa juruselamat yang disiapkan oleh Allah untuk menyelamatkan manusia dari dosa dan akibatnya, hanyalah Yesus Kristus dan sama sekali tidak ada yang lain (Kis. 4: 12). Itulah sebabnya manusia harus percaya dan menerima Yesus sebagai juruselamatnya.

Untuk mengetahui, mengapa manusia harus diselamatkan, maka yang harus dijadikan sumber data utama adalah Alkitab. Misalnya di dalam Perjanjian Lama, misalnya di dalam Kej. 2: 16-17 dan 3: 6 sudah sangat jelas dikatakan, bahwa manusia pertama berdosa, yaitu Adam dan Hawa sudah jatuh ke dalam dosa. Karena itu, kalau manusia pertama telah berdosa, maka bisa dipastikan keturunan manusia selanjutnyapun juga pasti berdosa, karena manusia itu adalah keturunan dari orangtuanya. Jadi bila orangtuanya berdosa, maka dapat dipastikan anak-anak dan keturunannya juga berdosa. Alkitab Perjanjian Baru juga mencatat dengan sangat jelas, bahwa manusia itu adalah manhluk yang berdosa. Misalnya dalam Rm. 3: 23 dikatakan, bahwa semua orang telah berbuat dosa dan telah kehilangan kemuliaan Allah. Artinya menurut Alkitab Perjanjian Baru, khususnya ayat di atas, bahwa tidak ada manusia yang tidak berdosa, karena di sana di katakan semua

\footnotetext{
${ }^{32}$ Harun Hadiwijono, Iman Kristen (Jakarta: BPK Gunung Mulia, 2010), 18

${ }^{33}$ Bruce Milne, Mengenali Kebenaran (Jakarta: BPK Gunung Mulia, 2009), 164

${ }^{34}$ Sumarsono, dkk._Pendidikan Kewarganegaraan (Jakarta: Gramedia, 2005), 43. Lihat juga Musthafa Kamal Pasha, Pancasila dalam Tinjauan Historis, Yuridis dan Filosofis (Yogyakarta : Citra Karsa Mandiri, 2005), 136.
} 
manusia telah berbuat dosa. Bruce Milne mengatakan kejatuhan manusia ke dalam dosa, juga berarti dunia sudah menjadi wilayah kegiatan kuasa kegelapan. ${ }^{35}$

Berkaitan dengan konsekwensi dan akibat dosa itu, maka yang dijadikan sumber datanya haruslah Alkitab juga, baik Perjanjian Lama dan juga Perjanjian Baru. Misalnya, Alkitab Perjanjian Lama mencatat di dalam Kejadian 3: 9 - 19, bahwa konsekwensi dan akibat dari keberdosaan manusia itu adalah penderitaan yang sangat mengerikan bagi manusia itu sendiri, baik selama manusia itu hidup di dunia, maupun sampai selamalamanya. Begitu juga catatan Alkitab Perjanjian Baru dapat dilihat, bahwa Alkitab Perjanjian Baru, khususnya di dalam Rm. 6: 23 dikatakan, bahwa upah dosa adalah maut. Maut yang diceritakan di sini adalah hal yang paling menakutkan yang akan dialami oleh manusia, karena dosa-dosanya. Dengan demikian, manusia sangat membutuhkan penyelesaian sesegeramungkin atas dosa-dosanya, sebab kalau tidak diselesaikan sesegeramungkin, maka penderitaan manusia akan semakin panjang dan bahkan sampai selamanya. Bruce Milne mengataka dosa itu mempengaruhi dan merusak hubungan manusia dengan Allah, sesamanya manusia, dirinya sendiri, alam semesta dan waktu. ${ }^{36}$ Itulah sebabnya Allah menunjukkan inisiatifnya untuk menyelamatkan manusia dari dosa dan akibatnya itu.

Ketika manusia jatuh ke dalam dosa dan hal itu membawa manusia ke dalam penderitaan di dalam kehidupannya, maka Alkitab mencatat, bahwa Allah berinisiatif untuk mencari dan menolong manusia itu (Kej. 3: ). Walaupun ternyata, manusia itu tidak bisa menerima kalau dirinya dipersalahkan. Itu sebabnya Adam menuduh, bahwa kesalahan itu ada pada diri Hawa dan Hawa juga tidak bisa menerima dirinya dipersalahkan, sehingga Hawapun menyebut kesalahan itu ada pada ular yang sudah memperdaya dirinya. Ketika Adam Hawa menolak inisiatif Allah untuk menolong manusia itu, namun Allah tidak berhenti berinisiatif untuk menolong dan menyelamatkan Adam Hawa. Itulah sebabnya, Allah mengutus nabi-nabinya untuk menolong manusia, seperti Nuh. Musa, Yesaya, Yeremia dan lain sebagainya. Para nabi yang diutus oleh Allah itupun ditolak oleh manusia (Kis. 7: 52). Allah tidak pernah berhenti berinisiatif untuk menolong dan menyelamatkan manusia.

Puncak dari inisiatif Allah untuk menolong dan menyelamatkan manusia dari dosa dan akibatnya itu adalah Allah mengutus anakNya sendiri. Allah merelakan anakNya yang tunggal Yesus Kristus menjadi manusia, mengambil rupa sebagai hamba, dianiaya dengan sadis, menderita bahkan sampai mati di salib demi menyelamatkan manusia dari dosa dan akibatnya (Fil. 2: 7-8). Walaupun manusia yang mau diselamatkanNya dan yang notabene adalah umat pilihanNya menganiaya, menyiksa dan membunuhNya, namun Allah tidak berhenti berinisiatif untuk menyelamatkannya. Selanjutnya Allah mengutus rasul-rasulnya untuk memberitakan Yesus Kristus adalah Tuhan dan juru selamat, mulai di sekitar mereka

\footnotetext{
${ }^{35}$ Milne, Mengenali Kebenaran, 171

${ }^{36}$ Ibid., 149-153
} 
dan sampai ke ujung-ujung bumi (Mat. 28: 19, Mrk. 16: 15, Kis. 1: 8). Karena puncak inisiatif Allah untuk menyelamatkan manusia adalah melalui Yesus, maka untuk memberitakan Yesus adalah Tuhan dan juru selamat, Allah mengutus setiap orang percaya untuk memberitakan hal itu. Bahkan demi mensosialisasikan inisiatif Allah dalam menyelematkan manusia itu hanya melalui Yesus, maka Allah "mengutus" Alkitab untuk memberitakan Yesus adalah Tuhan dan juru selamat satu-satunya, sehingga Alkitab sudah diterjemahkan ke dalam lebih dari 1200 bahasa.

Penterjemahan Alkitab itu dilakukan, supaya manusia dapat memahami inisiatif penyelamatan manusia di dalam bahasa ibunya masing-masing. Dengan mereka memahaminya, diharapkan mereka percaya dan menerima Yesus Kristus sebagai Tuhan dan juru selamatnya serta hidup di dalam imannya tersebut, sehingga dengan demikian mereka menjadi pengikut Yesus Kristus (Kristen) dan sekaligus mangalami kebahagiaan sejati selama mereka hidup di dalam dunia dan bahkan sampai selama-lamanya.

Bila disimpulkan, bahwa ada persamaan tujuan kebudayaan, termasuk adat istidat yang ada di dalamnya dengan tujuan Kristen, yaitu untuk membawa manusia kepada kebahagiaan dan keselamatan. Hanya saja, adat istiadat yang diciptakan oleh manusia bertujuan membawa kebahagiaan dan keselamatan bagi manusia selama di dunia, sementara keselamatan yang ditawarkan Yesus Kristus bagi para pengikutNya (Kristen) adalah kebahagiaan selama di dunia dan di akhirat.

Dunia sendiri memang pasti akan mengalami perubahan secara terus menerus, namun iman Kristen kepada Yesus Kristus tidak akan pernah berubah. Hanya saja strategi adaptasi atau cara menerapkan iman Kristen di dunia yang terus berubah itulah yang akan berubah dan disesuaikan dengan zamannya. Di samping itu, harus diketahui juga, bahwa manusia tidak akan dapat hidup dunia tanpa masyarakatnya, karena manusia itu mahluk sosial, yang mengharuskannya untuk bergaul, berteman dan bersahabat. Kumpulan orang-orang itulah yang kemudian disebut masyarakat, yang dalam bahasa Inggris disebut "society". 37 Masyarakat tidak akan dapat hidup tanpa kebudayaannya, termasuk adat istiadat yang ada di dalamnya, karena manusia sebagai mahluk sosial dalam relasinya dengan lingkungan sosial dan alamnya harus ada penataan atau aturan-aturan.

Dengan kata lain dapat dikatakan, manusia tidak akan bisa dipisahkan dengan kebudayaannya, termasuk dengan adat istiadatnya itu, karena adatistiadatnya itulah yang menjadi pedoman penataan kehidupannya yang berelasi dengan lingkungan sosial dan alamnya. Kebudayaan itu, sebenarnya bisa juga dikatakan sebagai strategi adaptasi hidup manusia dalam masyarakatnya, sehingga dia dapat bertahan hidup di lingkungan sosial, budaya dan alamnya, serta strategi adaptasi tersebut harus dipelajari oleh manusia, agar dapat menguasainya dengan lebih baik. Dalam istilah para Antropolog, proses mempelajari

\footnotetext{
${ }^{37}$ Koentjaraningrat, Pengantar Ilmu Antropologi, 143
} 
dan menguasai kebudayaan sendiri ini disebut juga proses internalisasi. ${ }^{38}$ Proses belajar strategi adaptasi (kebudayaan) itu berlangsung selama manusia itu hidup di dunia ini.

\section{PEMBAHASAN}

Bila diperhatikan di dalam kehidupan sehari-hari, maka akan terlihat ada tiga sikap Kristen terhadap kebudayaan, yakni: Mengadopsi adat istiadat tanpa seleksi ; Mengadopsi adat istiadat dengan seleksi; Menolak adat istiadat tanpa kompromi.

Mengadopsi adat istiadat yang tidak bertentangan dengan Alkitab tanpa terlebih dahulu melakukan penyeleksian, misalnya marga, tidak perlu dilekukan penyeleksian, "sangkep si telu" ("senina, kalimbubu dan anak beru” Batak Karo), juga tidak perlu diseleksi atau dimodifikasi oleh orang Kristen. Dalam upacara lingkaran hidup orang Batak Karo, "merga si lima" (marga yang lima), "sangkep si telu" (tungku yang tiga) dan "tutur si waluh" (aturan yang delapan) sangat berperan, sehingga proses pelaksanaan upacara adat istiadat dapat dilaksanakan dan berjalan dengan baik, tanpa harus membentuk kepanitiaan. Sistem organisasi sosial yang ada di sub suku-bangsa Batak Karo itu dan juga di dalam sub suku-bangsa Batak lainnya sudah dapat menyelesaikan seluruh kegiatan-kegiatan pribadi dan keluarganya di dalam masyarakatnya dengan teratur dan tertata dengan baik, karena itu tidak perlu di buat organisasi sosial yang baru bagi masyarakat tersebut. Karena itu, semua hal-hal yang baik, menguntungkan dan tidak bertentangan dengan ajaran Kristen, seharusnya diadopsi oleh generasi ini, sehingga kehidupannya menjadi lebih baik dan tertata. Jhon Chambers mengatakan tentu tidak semua kebudayaan (adat istiadat) yang bertentangan dengan Firman Tuhan. Ada banyak hal yang baik yang sejalan dan perlu dipertahankan sebagai ciri dan identitas dari suku-bangsa tertentu, walaupun sudah menjadi Kristen. ${ }^{39}$

Mengadopsi adat istiadat dengan seleksi, agar tidak lagi bertentangan dengan ajaran Alkitab, misalnya upacara 7 bulanan, masuk rumah baru, nabur benih, panen, pernikahan, kematian dan lain sebagainya. Selama ini upacara tujuh bulanan ini dilakukan di dalam kepercayaan lama yang berbeda dengan ajaran Kristen, maka sekarang setelah menjadi Kristen, maka kegiatan-kegiatan itu dimulai dan dilakukan sesuai dengan ajaran Kristen, dalam nama Allah Bapa, AnakNya Yesus Kristus dan Roh Kudus. Dengan kata lain, kegiatan-kegiatan di dalam lingkaran hidup masyarakat yang banyak itu, harus diseleksi dan dimodifikasi dengan pembelajaran yang baik, sehingga dalam penerapannya tidak menjadi sinkritis, yang tentunya sinkritis bertentangan dengan ajaran Kristen. John Chambers mengatakan: "Banyak orang cenderung menerima adatistiadat secara membabi buta, tanpa mengkaji secara kritis makna dan tujuan upacara tersebut dari sudut pandang Firman Tuhan dan dampaknya bagi ibadah kepada Tuhan." 40

\footnotetext{
${ }^{38}$ Ibid., 228

${ }^{39}$ Chambers, Pasang, Cara Pandang Kristen, 166

${ }^{40}$ Ibid., 169
} 
Menolak adat istiadat yang bertentangan dengan ajaran Alkitab, misalnya upacara adat istiadat atau kegiatan lain yang merupakan bagian dari upacara kepercayaan lain yang bukan Kristen, maka hal itu harus ditolak , misalnya mengundang dan melibatkan orang pintar atau para normal atau dukun dalam proses kehidupan pribadi, keluarga dan masyarakat yang beragama Kristen, apakah dalam bentuk simbol dan khususnya langsung. John Chambers mengatakan praktek pemujaan/berpaling kepada arwah nenek moyang dan roh-roh peramal sangat dibenci oleh Tuhan, karena itu harus dijauhkan oleh orang Kristen. ${ }^{41}$ Mengikuti cara dan gaya hidup dunia ini yang cenderung menghalalkan segala hal untuk mencapai tujuannya, seperti bermalas-malasan, menipu, menyogok dan hal-hal lain yang bertentangan dengan ajaran Kristen harus dijauhkan dari kehidupan orang, keluarga dan masyarakat yang beragama Kristen, karena hal itu bertentangan dengan iman Kristen atau ajaran Alkitab (bd. 10 hukum Tuhan). Orang Kristen tidak dibenarkan mengikuti cara hidup dunia ini (bd. Rm. 12: 2).

\section{KESIMPULAN}

Kebudayaan dan adat istiadat yang ada di dalamnya adalah produk berfikir, berasa dan berkehendak manusia, agar dapat bertahan hidup dilingkungan alam, budaya dan sosialnya. Dengan demikian, bisa dikatakan, bahwa manusia yang adalah mahluk sosial itu, tidak mungkin hidup tanpa kebudayaan dan adat istiadatnya, karena kebudayaan dan adat istiadatnya itu menyatu dengan dirinya. Dengan kata lain manusia tidak mungkin dipisahkan dari kebudayaan dan adat istiadatnya. Karena itu, kekristenan juga harus melihat manusia sebagai mahkluk sosial yang lengkap dan menyatu dengan kebudayaan dan adat istiadat yang dimilikinya.

\section{REFERENSI}

Alkitab, LAI, Jakarta, 1979 (TB).

Chambers, John - Haskarlianus Pasang. Cara Pandang Kristen. Langham, Bogor, 2015

Hadiwijono, Harun. Iman Kristen. BPK Gunung Mulia, Jakarta, 2010

Kuiper, Arie de. Missiologia. BPK Gunung Mulia, Jakarta, 2010

Koentjaraningrat (ed). Manusia dan kebudayaan di Indonesia Djambatan, Jakarta, 2002.

Koentjaraningrat. Pengantar Ilmu Antropologi. Djambatan, Jakarta, edisi revisi 2009

Mauludi, Sahrul (ed). Penyerbukan Silang Antarbudaya Membangun Manusia Indonesia. Kompas Gramedia, Jakarta, 2015.

Milne, Bruce. Mengenal Kebenaran. BPK Gunung Mulia, Jakarta, 2009

Pasha, Musthafa Kamal. Pancasila Dalam Tinjauan Historis, Yuridis dan Filosofis. Citra Karsa mandiri, Yogyakarta, 2005

Ranjabar. Jakobus. Perubahan Sosial Teori-teori dan Prosse Perubahan Sosial Serta Teori Pembangun. Alfabeta, Bandung, 2015

Sumarsono, dkk. Pendidikan Kewarganegaraan. Gramedia, Jakarta, 2015

\footnotetext{
${ }^{41}$ Ibid., 171
} 